\title{
TRANSAKSI VALUTA ASING (AL-SHARF) \\ DALAM PERSPEKTIF ISLAM
}

\author{
Muhammad Sulhan \\ Fakultas Ekonomi Universitas Islam Negeri (UIN) Malang \\ Jl. Gajayana No. 50, Telepon (0341) 558881, Fax. (0341) 558881, \\ E-mail: feuinmlg@yahoo.co.id
}

\begin{abstract}
The written text attempts to explain transactional problem (trade) foreign exchange of Islamic law trade. It is caused by the international trade phenomena that won't be free from state currency one another as a payment tool in which accelerate the traffic of international trade activity. The necessity of currency conversion in the international trade will bring up out of foreign exchange demand and supply in the foreign exchange market; it will cause foreign exchange trade transaction at last. Based on the variety of Islamic laws analysis, it is known that the foreign currency trade practice (al-sharf) is allowed if done based on each other agreement and cash, not to have a speculation (undertake something hoping for the best), there is transactional needed or aware of (saving), and if the transaction done toward the same type of currency so, it must have the same value and if it's different, it must be done using prevailed rate of exchange (kurs) in the moment of transaction. The following types of foreign exchange transaction in the foreign exchange market, it is only spot transactional type allowed, meanwhile forward, swap, and option are forbidden because they aren't cash and contain of maisir (speculation). Besides, the participants should pay more attention toward constrains of foreign exchange trade transaction and they should be able to avoid divergences that are forbidden in Islamic of syariah trade like extortionate, forcing and many others. In this case, these cause the transaction of foreign exchange trade is prohibited.
\end{abstract}

key words: foreign exchange transaction, spot, speculation, norm of islamic law

Seiring dengan adanya era globalisasi dan kemajuan teknologi informasi dewasa ini menjadikan dunia seakan-akan tanpa batas dan perekonomian antar negara menjadi semakin saling terintegrasi dan terkait. Hal ini menyebabkan perkembangan perekonomian suatu negara tidak hanya ditentukan oleh perekonomian negara itu sendiri, tetapi juga akan selalu terkait dengan sistem perekonomian global, khususnya dalam bidang perdagangan internasional. 
Kegiatan perdagangan Internasional selalu memerlukan transfer dan konversi mata uang dari satu negara ke negara lain. Hal ini disebabkan setiap negara merdeka didunia ini mempunyai wewenang untuk menentukan mata uang yang digunakan dan nilai kursnya (nilai tukar mata uang suatu negara dengan negara lain). Seandainya di dunia ini ada mata uang tunggal internasional, barangkali konversi mata uang yang satu dengan mata uang yang lain tidak diperlukan dalam melakukan perdagangan internasional. Dengan kata lain, terdapat kebutuhan untuk mengkonversi mata uang yang satu dengan mata uang yang lain dalam lalu lintas perdagangan internasional tersebut. Inilah yang akan mendorong terjadinya penawaran dan permintaan akan valuta asing, yang pada gilirannya akan melahirkan transaksi (jual beli) valuta asing di pasar valas.

Transaksi valuta asing akan selalu tergantung oleh nilai kurs mata uang suatu negara dan dapat saja berubah sewaktu-waktu, sesuai dengan kondisi perekonomian negara tersebut. Adanya fluktuasi nilai kurs dan kebutuhan akan konversi mata uang tersebut akan menarik pihak-pihak yang berkepentingan terhadap valuta asing seperti investor, exportir, importir atau bahkan spekulan untuk melakukan transaksi valuta asing. Yang menarik sekarang untuk dikaji adalah bagaimana transaksi jual beli valuta asing dalam perspektif perdagangan hukum Islam

\section{TRANSAKSI VALUTA ASING}

\section{Pengertian}

Yang dimaksud dengan valuta asing adalah mata uang luar negeri seperi dolar Amerika, poundsterling Inggris, ringgit Malaysia dan sebagainya. Apabila antara negara terjadi perdagangan internasional maka tiap negara membutuhkan valuta asing untuk alat bayar luar negeri yang dalam dunia perdagangan disebut devisa. Misalnya eksportir Indonesia akan memperoleh devisa dari hasil ekspornya, sebaliknya importir Indonesia memerlukan devisa untuk mengimpor dari luar negeri.

Dalam beberapa kamus bahasa arab transaksi valuta asing di istilahkan dengan kata alsharf yang berarti jual beli valuta asing atau dalam istilah bahasa inggris adalah money changer. Menurut Taqiyuddin an-Nabhani mendefinisikan al-sharf dengan pemerolehan harta dengan harta lain, dalam bentuk emas dan perak, yang sejenis dengan saling menyamakan antara emas yang satu dengan emas yang lain, atau antara perak satu dengan perak yang lain (atau berbeda sejenisnya) semisal emas dengan perak, dengan menyamakan atau melebihkan antara jenis yang satu dengan jenis yang lain. (Thaher : 2007) 
Berdasarkan pengertian al-sharf diatas, maka dapat ditarik kesimpulan bahwa as-sharf merupakan suatu perjanjian jual beli suatu valuta dengan valuta lainnya, transaksi jual beli mata uang asing yang sejenis (misalnya rupiah dengan rupiah) maupun yang tidak sejenis (misalnya rupiah dengan dolar atau sebaliknya). Dalam literatur klasik, ditemukan dalam bentuk jual beli dinar dengan dinar, dirham dengan dirham atau dinar dengan dirham. Tukar menukar seperti ini dalam hukum islam termasuk salah satu cara jual beli, dan dalam hukum perdata Barat disebut dengan barter.

Adapun aktivitas-aktivitas yang dapat dikategorikan dalam transaksi jual beli mata uang menurut Taqiyuddin an-Nabhani meliputi :

1. Pembelian mata uang dengan mata uang yang serupa seperti pertukaran uang kertas dinar baru dengan kertas dinar lama

2. Pertukaran mata uang asing seperti pertukaran dolar dengan Pound Mesir

3. Pembelian barang dengan uang tertentu serta pembelian mata uang tersebut dengan mata uang asing seperti membeli pesawat dengan dolar, serta pertukaran dolar dengan dinar Irak dalam suatu kesepakatan

4. Penjualan barang dengan mata uang, misalnya dengan dolar Australia

5. Penjualan promis (surat perjanjian untuk membayar sejumlah uang) dengan mata uang tertentu

6. Penjualan saham dalam perseroan tertentu dengan mata uang tertentu

Dewasa ini transaksi jual beli valuta asing umumnya dapat dilakukan di bursa atau pasar valas yang bersifat internasional. Pasar valas menyediakan sarana fisik dan institusional untuk melakukan perdagangan valuta asing, menentukan nilai tukar dan menerapkan manajemen valuta asing. Pasar valas ini dapat menjalankan beberapa fungsi antara lain: Pertama, sebagai mekanisme dimana orang dapat mentransfer daya beli antar negara; Kedua, sebagai tempat untuk mendapatkan atau menyediakan kredit untuk transaksi perdagangan internasional; dan Ketiga, sebagai wahana untuk meminimalkan kemungkinan resiko kerugian akibat terjadinya fluktuasi kurs suatu mata uang. (Yuliati : 2002)

\section{Tipe - Tipe Transaksi Valuta Asing Dan Partisipan Dalam Valuta Asing}

Ada beberapa jenis tipe - tipe transaksi valuta asing yang terjadi di pasar valas, yaitu spot, forward, dan swap (Hanafi :2004)

1. Transaction Spot (transaksi spot) 
Transaksi spot merupakan transaksi valuta asing dengan penyerahan dan pembayaran saat itu juga, meskipun dalam praktek transaksi spot akan diselesaikan pada dua hari kerja berikutnya. Misalnya kontrak jual beli suatu mata uang spot dilakukan atau ditutup pada tanggal 10 agustus 2007, penyerahan dan penyelesaian kontrak tersebut dilakukan pada tanggal 12 agustus 2007, apabila tanggal 12 agustus 2007 tersebut kebetulan hari libur atau hari sabtu maka penyelesaiannya adalah pada hari kerja berikutnya dan penyelesaian transaksi seperti ini disebut value date. Penyerahan dana dalam transaksi spot pada dasarnya dapat dilakukan dalam beberapa cara berikut ini (Kuncoro : 2001) :

a) Cash, yaitu penyerahan dana dilakukan pada tanggal (hari) yang sama dengan tanggal (hari) diadakannya transaksi (kontrak).

b) Tom (kependekan dari tomorrow), yaitu penyerahan dana dilakukan pada hari kerja berikutnya atau hari kerja setelah diadakannya kontrak.

c) Spot, yaitu penyerahan dilakukan dua hari kerja setelah tanggal transaksi.

2. Forward Transaction (Transaksi berjangka)

Transaksi forward merupakan transaksi valuta asing dengan penyerahan pada beberapa waktu mendatang sejumlah mata uang tertentu berdasarkan sejumlah mata uang tertentu yang lain. Kurs dalam transaksi forward ditentukan di muka sedangkan penyerahan dan pembayaran dilakukan beberapa waktu mendatang pada saat kontrak jatuh tempo.

Transaksi forward ini biasanya sering digunakan untuk tujuan hedging dan spekulasi. Hedging atau pemagaran resiko yaitu transaksi yang dilakukan semata-mata untuk menghindari resiko kerugian akibat terjadinya perubahan kurs.

\section{Swap Transaction (Transaksi Swap)}

Yaitu transaksi pembelian dan penjualan bersamaan sejumlah tertentu mata uang dengan 2 tanggal valuta (penyerahan) yang berbeda. Pembelian dan penjualan mata uang tersebut dilakukan pada bank lain yang sama. Jenis transaksi swap yang umum adalah spot terhadap forward. Dealer membeli suatu mata uang dengan transaksi spot dan secara simultan menjual kembali jumlah yang sama kepada bank lain yang sama dengan kontrak forward. Karena itu dilakukan sebagai suatu transaksi tunggal dengan bank lain yang sama, dealer tidak akan menghadapi resiko valas yang tidak diperkirakan.

Seperti dijelaskan diatas bahwa pada prinsipnya transaksi swap merupakan transaksi tukar pakai suatu mata uang untuk jangka waktu tertetu. Transaksi swap berbeda dengan 
transaksi spot atau forward. Dalam mekanisme swap, terjadi dua transaksi sekaligus dalam waktu yang bersamaan yaitu menjual dan membeli. Penggunaan transaksi swap sebenarnya dimaksudkan untuk menjaga kemungkinan timbulnya kerugian yang disebabkan oleh perubahan kurs suatu mata uang. Swap dapat dilakukan antara nasabah dengan banknya dan antara bank dengan bank Indonesia (disebut reswap). Pemberian fasilitas reswap tersebut dilakukan atas dasar swap point yang ditetapkan oleh bank Indonesia.Transaksi swap antara bank dengan BI antara lain:

a) Swap likuiditas, yaitu swap yang dilakukan atas inisiatif BI untuk dana yang berasal dari pinjaman luar negeri. Posisi likuiditas ini untuk setiap bank maksimum $20 \%$ dari modal bank tersebut.

b) Swap investasi, yaitu swap yang dilakukan atas inisiatif bank berdasarkan swap dengan nasabah yang adanya berasal dari pinjaman luar negeri untuk keperluan investasi di Indonesia.

c) Perbedaan dari ketga jenis transaksi di atas adalah bahwa swap terjadi dua transaksi pada saat yang sama (double transaction), yaitu jual beli atau beli dan jual. Sedangkan pada spot dan forward hanya terjadi satu kali transaksi saja (one single transaction), yaitu jual beli saja.

4. Option Transaction (Transaksi Opsi)

Transaksi Opsi merupakan kontrak untuk memperoleh hak dalam rangka membeli atau hak untuk menjual yang tidak harus dilakukan atas sejumlah unit valuta asing pada harga dan jangka waktu tertentu.

Di tinjau dari jenis hak yang diberikan, maka terdapat dua jenis opsi, yaitu opsi call dan opsi put. Opsi call memberi hak kepada pemegang opsi untuk membeli mata uang dengan nilai tukar tertentu yang telah disepakati (strike price/exercise price). Sementara opsi put memberi hak kepada pembelinya untuk menjual mata uang pada strike price. Pada umumnya pembeli opsi call akan menggunakan haknya jika strike price lebih rendah dari spot rate. Sebaliknya, pemegang opsi put akan menjalankan haknya jika strike price lebih tinggi dari spot rate. Pada kedua kondisi tersebut pemegang opsi call dan opsi put berada pada kondisi in the money.

Transaksi yang terjadi di pasar valuta asing dapat di bedakan menjadi dua golongan yaitu antar bank (wholesale market) dan klien (retail market). Transaksi yang terjadi dalam pasar antar bank (wholesale market) biasanya berjumlah sangat besar misalnya dalam kelipatan jutaan 
dolar. Sedangkan kontrak antar bank dengan nasabah (retail market) biasanya dibuat dalam jumlah tertentu dan bisa dalam jumlah yang relatif kecil.

Adapun partisipan/peserta yang aktif melakukan transaksi pada dua tingkat pasar di atas terdiri dari lima kategori partisipan, yaitu (Yuliati : 2002):

a. Dealer valuta asing bank dan non bank

Dealer bank-bank dan non bank beroperasi dikedua pasar antar bank dan nasabah. Mereka ini memperoleh keuntungan dengan membeli valuta asing pada harga permintaan (bid) dan menjualnya kembali pada harga yang sedikit lebih tinggi daripada harga penawaran (offer).

b. Perusahaan dan individu

Perusahaan dan individu menggunakan pasar valuta asing untuk mempermudah pelaksanaan transfer investasi atau komersil. Kelompok ini terdiri dari para importir, investor internasional, perusahaan-perusahaan multinasional. Mereka menggunakan pasar valuta asing untuk tujuan investasi.

c. Spekulator dan arbitrase

Mereka ini melakukan transaksi dalam pasar valuta asing untuk memperoleh keuntungan. Arbitrase pada prinsipnya merupakan suatu bentuk spekulasi yang terdapat dalam valuta asing, dimana mereka membeli suatu valuta asing di suatu pusat keuangan kemudian menjualnya kembali di pusat keuangan lain untuk memperoleh keuntungan. Kegiatan arbitrase ini dimungkinkan oleh mudah dan cepatnya dilakukan transfer dengan menggunakan alat telegrafik antara pusat keuangan satu dengan pusat keuangan dunia lainnya. Motif mereka ini berbeda dengan dealer, karena spekulator dan arbitrase beroperasi hanya untuk kepentingan mereka sendiri tanpa suatu kebutuhan atau kewajiban untuk melayani klien atau untuk memastikan kontinuitas pasar. Sedangkan dealer mencari keuntungan dari spread antara permintaan dan penawaran dan hanya secara insidentil mencari keuntungan dari perubahan-perubahan harga. Sementara spekulator mencari seluruh keuntungan dari perubahan-perubahan harga secara simultan. Spekulasi dan arbitrase dalam jumlah besar biasanya dilakukan oleh trader. Bank-bank dalam hal ini dapat bertindak sebagai dealer, spekulator dan arbitrase.

d. Bank Sentral 
Bank-bank sentral menggunakan pasar ini untuk memperoleh cadangan devisa dan juga mempengaruhi harga dimana mata uangnya diperdagangkan. Bank sentral mungkin melakukan langkah-langkah yang semata-mata dimaksudkan untuk mendukung atau mendongkrak nilai mata uang sendiri. Kebijakan atau strategi seperti ini banyak dilakukan oleh bank-bank sentral.

e. Pialang valuta asing

Pialang valuta asing berfungsi sebagai perantara yang mempertemukan penawaran dan permintaan terhadap mata uang tertentu. Pialang valuta asing bertindak atas nama klien dan atas jasanya tersebut mereka memperoleh komisi sebagai kontra prestasi. Agar dapat menjalankan fungsinya dengan baik, perusahaan pialang memiliki akses langsung dengan dealer dan bank di seluruh dunia.

\section{Analisis Transaksi Valuta Asing (Al-Sharf) Berdasarkan Norma-Norma Hukum Islam}

Pada prinsipnya praktek jual beli seperti al-sharf diperbolehkan dalam Islam bedasarkan firman Allah dalam surat al-Baqarah ayat 275: "...Dan Allah telah menghalalkan jual beli dan mengharamkan riba....". Disamping firman Allah diatas, ada beberapa hadist Rosulullah yang berkaitan dengan transaksi al-sharf, antara lain :

1. Hadits Nabi riwayat al-Baihaqi dan Ibnu Majah dari Abu Sa'id al-Khudri: Rasulullah SAW bersabda, "Sesungguhnya jual beli itu hanya boleh dilakukan atas dasar kerelaan (antara kedua belah pihak)" (HR. al-Baihaqi dan Ibnu Majah, dan dinilai shahih oleh Ibnu Hibban),

2. Hadits Nabi riwayat Muslim, Abu Daud, Tirmizi, Nasa'i, dan Ibn Majah, dengan teks Muslim dari ‘Ubadah bin Shamit, Nabi s.a.w. bersabda: “(Juallah) emas dengan emas, perak dengan perak, gandum dengan gandum, sya'ir dengan sya'ir, kurma dengan kurma, dan garam dengan garam (dengan syarat harus) sama dan sejenis serta secara tunai. Jika jenisnya berbeda, juallah sekehendakmu jika dilakukan secara tunai."

3. Hadits Nabi riwayat Muslim, Tirmidzi, Nasa'i, Abu Daud, Ibnu Majah, dan Ahmad, dari Umar bin Khatthab, Nabi s.a.w. bersabda: "(Jual beli) emas dengan perak adalah riba kecuali (dilakukan) secara tunai." Hadits Nabi riwayat Muslim dari Abu Sa'id al-Khudri, Nabi s.a.w. bersabda: “Janganlah kamu menjual emas dengan emas kecuali sama (nilainya) dan janganlah menambahkan sebagian atas sebagian yang lain; janganlah menjual perak dengan perak kecuali sama (nilainya) dan janganlah menambahkan sebagian atas sebagian yang lain; dan janganlah menjual emas dan perak tersebut yang tidak tunai dengan yang 
tunai." Hadits Nabi riwayat Muslim dari Bara' bin 'Azib dan Zaid bin Arqam: "Rasulullah saw melarang menjual perak dengan emas secara piutang (tidak tunai)."

Pada prinsip syariahnya, praktek jual beli valuta asing dapat dianalogikan dan dikategorikan dengan pertukaran antara emas dan perak atau dikenal dalam terminologi fiqih dengan istilah (al-sharf) yang disepakati para ulama tentang keabsahannya. Dari beberapa hadist diatas, dapat dijelaskan sebenarnya praktek al-sharf diperbolehkan jika dilakukan atas dasar kerelaan antara kedua belah pihak dan secara tunai, serta tidak boleh adanya penambahan antara suatu barang yang sejenis (emas dengan emas atau perak dengan perak), karena kelebihan antara dua barang yang sejenis tersebut merupakan riba al-fadl yang jelas-jelas dilarang oleh Islam.

Namun bila berbeda jenisnya, seperti emas dengan perak atau dalam mata uang sekarang misalnya Rupiah dengan Dolar atau sebaliknya maka dapat ditukarkan (exchange) sesuai dengan market rate (harga pasar) dengan catatan harus kontan/spot. Adapun kriteria 'tunai' atau 'kontan' dalam jual beli yang dikembalikan kepada kelaziman pasar yang berlaku meskipun hal itu melewati beberapa jam penyelesaian (settelment-nya) karena proses teknis transaksi. Harga atas pertukaran itu dapat ditentukan berdasarkan kesepakatan antara penjual dan pembeli atau harga pasar (market rate). Kriteria tunai (kontan) dalam praktek al-sharf seperti hadits diatas adalah untuk menghindari terjadinya riba nasi'ah.

Adapun berdasarkan fatwa Dewan Syariah Nasional Nomor: 28/DSN-MUI/III/2002 tentang $A l$ - Sharf, transaksi jual beli mata uang pada prinsipnya boleh dengan ketentuan sebagai berikut:

1. Tidak untuk spekulasi (untung-untungan)

2. Ada kebutuhan transaksi atau untuk berjaga-jaga (simpanan)

3. Apabila transaksi dilakukan terhadap mata uang sejenis maka nilainya harus sama dan secara tunai (at-taqabudh).

4. Apabila berlainan jenis maka harus dilakukan dengan nilai tukar (kurs) yang berlaku pada saat transaksi dilakukan dan secara tunai.

Sedangkan ketentuan mengenai hukum jenis-jenis transaksi valuta asing yang ada di pasar valas dijelaskan dalam fatwa tersebut sebagai berikut:

1. Transaksi Spot, yaitu transaksi pembelian dan pen-jualan valuta asing (valas) untuk penyerahan pada saat itu (over the counter) atau penyelesaiannya paling lambat dalam 
jangka waktu dua hari. Hukumnya adalah boleh, karena dianggap tunai, sedangkan waktu dua hari dianggap sebagai proses penyelesaian yang tidak bisa dihindari dan merupakan transaksi internasional.

2. Transaksi Forward, yaitu transaksi pembelian dan penjualan valas yang nilainya ditetapkan pada saat sekarang dan diberlakukan untuk waktu yang akan datang, antara $2 \times 24$ jam sampai dengan satu tahun. Hukumnya adalah haram, karena harga yang diguna-kan adalah harga yang diperjanjikan (muwa'adah) dan penyerahannya dilakukan di kemudian hari, padahal harga pada waktu penyerahan tersebut belum tentu sama dengan nilai yang disepakati, kecuali dilakukan dalam bentuk forward agreement untuk kebutuhan yang tidak dapat dihindari (lil hajah).

3. Transaksi Swap, yaitu suatu kontrak pembelian atau penjualan valas dengan harga spot yang dikombinasi-kan dengan pembelian antara penjualan valas yang sama dengan harga forward. Hukumnya haram, karena mengandung unsur maisir (spekulasi).

4. Transaksi Option, yaitu kontrak untuk memperoleh hak dalam rangka membeli atau hak untuk menjual yang tidak harus dilakukan atas sejumlah unit valuta asing pada harga dan jangka waktu atau tanggal akhir tertentu. Hukumnya haram, karena mengandung unsur maisir (spekulasi).

Berdasarkan fatwa Dewan Syariah Nasional Nomor: 28/DSN-MUI/III/2002 tentang Al - Sharf di atas, jelas sekali dapat disimpulkan bahwa dari beberapa jenis tipe transaksi valuta asing di pasar valas hanya tipe transaksi spot yang diperbolehkan. Sedangkan untuk tipe transaksi forward, swap, dan option tidak diperbolehkan karena tidak dilakukan secara tunai dan mengandung unsur maisir (spekulasi).

Tujuan dari keharusan tunai dalam akad al-sharf ini adalah untuk menghindari adanya gharar yang terdapat dalam riba fadl. Dengan adanya transaksi valuta asing dilaksanakan secara tunai, maka gharar dalam akad al-sharf ini akan hilang karena time of settlement-nya dilaksanakan pada saat itu juga secara tunai. Sedangkan dalam akad yang obyeknya berupa barang, maka selain masa penyerahannya yang harus tunai, juga harus sama dalam hal kualitas dan kuantitasnya. Oleh karena itu harus dilakukan secara simultan (taqabud) dalam melakukan transaksi jual beli valuta asing.

Sebagai salah satu variasi jual beli, al-sharf juga tentu saja harus memenuhi persyaratan sebagaimana halnya variasi jual beli yang lain seperti bai' mutlak dan muqayyadah. Karena agar 
jual beli itu terbentuk dan sah diperlukan sejumlah syarat, yaitu syarat adanya aqad jual beli dan syarat sahnya jual beli. Sedangkan aqad jual beli itu tidak saja ada dan terbentuk, akan tetapi juga sah secara hukum. Dengan demikian hukum tentang al-sharf yang biasa diartikan dengan jual beli valuta asing tidak diragukan lagi kebolehannya dari sudut fiqh Islam.

Berdasarkan pada norma -norma hukum islam diatas yang dijadikan dasar diperbolehkannya kegiatan transaksi jual beli valuta asing, maka ada beberapa batasan yang perlu diperhatikan dalam melakukan transaksi jual beli valuta asing tersebut antara lain :

1. Pertukaran tersebut harus dilakukan secara tuani (bai'naqd), artinya masing-masing pihak harus menerima atau menyerahkan masing-masing mata uang secara bersamaan.

2. Motif pertukaran adalah raagka mendukung transaksi komersil, yaitu transaksi perdagangan barang dan jasa antar bangsa, bukan dalam rangka spekulasi.

3. Harus dihindari jual beli bersyarat. Misalnya A setuju membeli barang dari B hari ini, dengan syarat B harus membelinya kembali pada tanggal tertentu di masa mendatang. Hal ini tidak diperbolehkan karena selain untuk menghindari riba. Juga karena jual beli barsyarat itu membuat hukum jual beli menjadi belum tuntas.

4. Transaksi berjangka harus dilakukan dengan pihak-pihak yang diyakini mampu menyediakan valuta asing yang dipertukarkan.

5. Tidak dibenarkan menjual barang yang belum dikuasai, atau dengan kata lain tidak dibenarkan jual beli tanpa hak kepemilikan (bai' ainiyah).

Akhirnya para partisipan yang melakukan transaksi jual beli valuta asing harus memperhatikan ketentuan tersebut diatas dan hendaknya menjauhkan diri dari pasar gelap karena dalam pasar gelap umumnya akan banyak terjadi penyimpangan-penyimpangan dalam melakukan transaksi valuta asing tersebut. Jika mereka melakukan penyimpangan dalam melakukan aktivitas transaksi valuta asing seperti melakukan pemerasan dan sejenisnya, maka yang semula halal akan menjadi terlarang kegiatan transakasi valuta asing tersebut karena dapat merugikan salah satu pihak yang lain.

\section{KESIMPULAN}

Transaksi jual beli valuta asing pada dasarnya timbul karena adanya kebutuhan konversi mata uang mata uang yang satu dengan mata uang yang lain dalam lalu lintas perdagangan internasional. Ini dikarenakan setiap negara yang melakukan aktivitas 
perdagangan internasional (Ekspor-Impor) tentu akan memerlukan alat bayar yaitu mata uang dari negara yang menjadi mitra dagangnya dan masing-masing negara mempunyai ketentuan sendiri dan berbeda satu sama lainnya dalam menentukan jenis dan nilai mata uangnya..

Nilai mata uang suatu negara dengan negara lainnya akan berubah (berfluktuasi) setiap saat sesuai volume permintaan dan penawaran dari mata uang tersebut di bursa atau pasar yang bersifat internasional. Adanya permintaan dan penawaran akan valuta asing inilah yang akhirnya menimbulkan transaksi jual beli valuta asing.

Pada prinsip syariahnya, yang didasarkan pada norma-norma hukum islam bahwa praktek jual beli valuta asing (al-sharf) diperbolehkan jika dilakukan atas dasar kerelaan antara kedua belah pihak dan secara tunai, serta tidak boleh adanya penambahan antara suatu barang yang sejenis (emas dengan emas atau perak dengan perak). Tetapi apabila berbeda jenisnya, seperti emas dengan perak atau dalam mata uang sekarang misalnya Rupiah dengan Dolar atau sebaliknya maka dapat ditukarkan sesuai dengan market rate (harga pasar) dengan catatan harus kontan (spot).

Hal ini juga sejalan dengan fatwa Dewan Syariah Nasional Nomor: 28/DSNMUI/III/2002 yang memperbolehkan transaksi jual beli mata uang dengan ketentuan antara lain: tidak untuk spekulasi (untung-untungan), ada kebutuhan transaksi atau untuk berjagajaga (simpanan), dan apabila transaksi dilakukan terhadap mata uang sejenis maka nilainya harus sama dan secara tunai (at-taqabudh), serta apabila berlainan jenis maka harus dilakukan dengan nilai tukar (kurs) yang berlaku pada saat transaksi dilakukan dan secara tunai. Akhirnya hendaknya para pelaku jual beli valuta asing dapat menghindari penyimpanganpenyimpangan yang dilarang dalam melakukan transaksi valuta asing sehingga jual beli valuta asing yang dilakukannya diperbolehkan menurut syariah Islam.

\section{DAFTAR PUSTAKA}

Hanafi, Mamduh. 2004. Manajemen Keuangan Internasional. Cetakan Pertama. Yogyakarta: BPFE. Kuncoro, Mudrajat. 2001. Manajemen Keuanagan Internasional. Edisi 2. Yogyakarta: BPFE. Madura, Jeff. 2006. Keuntungan Perusahaan Internasional.Edisi 8. Jakarta: Salemba Empat. MUI. 2008. Jual Beli Mata Uang. (online), (http:/ / www. mui.or.id) 
Sartono, Agus. 2003. Manajemen Keuangan Internasional. Cetakan Pertama.Yogyakarta: BPFE.

Thaher, Asmuni. 2007. Jual Beli Valuta Asing.(online), (http://www.msi-uii.net).

Yuliati, Sri Handaru dan Prasetyo, Handoyo. 2002. Dasar-dasar Manajemen Keuangan Internasional. Edisi Revisi. Yogyakarta: ANDI.

Yusgiantoro, Purnomo. 2004. Manajemen Keuangan Internasional: Teori dan Praktik. Jakarta: Penerbit Fakultas Ekonomi Universitas Indonesia. 